\title{
Dual inhibition of EGFR and c-Met kinase activation by MJ-56 reduces metastasis of HT29 human colorectal cancer cells
}

\author{
HUI-JYE CHEN ${ }^{1}$, YI-LIN JIANG ${ }^{2}$, CHUNG-MING LIN ${ }^{6}$, SHIH-CHANG TSAI ${ }^{3}$, SHU-FEN PENG ${ }^{3,5}$, \\ SHINJI FUSHIYA ${ }^{7}$, MANN-JEN HOUR ${ }^{4}$ and JAI-SING YANG ${ }^{2}$ \\ ${ }^{1}$ Graduate Institute of Molecular Systems Biomedicine, Departments of ${ }^{2}$ Pharmacology and ${ }^{3}$ Biological Science \\ and Technology, ${ }^{4}$ School of Pharmacy, China Medical University; ${ }^{5}$ Department of Medical Research, \\ China Medical University Hospital, Taichung 404; ${ }^{6}$ Department of Biotechnology, Ming Chuan University, \\ Taoyuan 333, Taiwan, R.O.C.; ${ }^{7}$ Department of Kampo Pharmaceutical Sciences, \\ Nihon Pharmaceutical University, Saitama 362-0806, Japan
}

Received March 4, 2013; Accepted April 9, 2013

DOI: 10.3892/ijo.2013.1941

\begin{abstract}
Quinazolinone derivatives are known to possess anticancer activities on cell metastasis and cell death in different human cancer cell lines. Here, we studied the anti-metastasis activity and the underlying mechanisms of the novel quinazoline derivative MJ-56 (6-pyrrolidinyl-2-(3-bromostyryl) quinazolin-4-one). MJ-56 inhibited cell migration and invasion of HT29 human colorectal cancer cells by wound-healing and Matrigel-coated transwell assays in a concentration-dependent manner. MJ-56-treated cells resulted in the reduced expression of matrix metalloproteinase (MMP)-2, -7, -9 and -10 and the reduced enzymatic activities of MMP-2 and MMP-9. In contrast, MJ-56-treated cells enhanced the expression of the tissue inhibitors of metalloproteinases (TIMPs) TIMP-1 and TIMP-2. Further analyses showed that MJ-56 attenuated the activities of epidermal growth factor receptor (EGFR), c-Met and the downstream ERK-mediated MAPK and PI3K/AKT/ mTOR signaling pathways, which led to decreased protein synthesis by dephosphorylating the translation initiation factors eIF-4B, eIF-4E, eIF-4G and S6 ribosomal protein. In addition, MJ-56 interfered with the NF- $\mathrm{kB}$ signaling via impairing PI3K/AKT activation and subsequently reduced the NF- $\mathrm{KB}$-mediated transcription of MMPs. Taken together, the reduced expression of phosphor-EGFR and c-MET is chiefly responsible for all events of blocking metastasis. Our results
\end{abstract}

Correspondence to: Dr Jai-Sing Yang, Department of Pharmacology, China Medical University, 91 Hsueh-Shih Road, Taichung 40402, Taiwan, R.O.C.

E-mail: jaising@mail.cmu.edu.tw

Dr Mann-Jen Hour, School of Pharmacy, China Medical University, 91 Hsueh-Shih Road, Taichung 40402, Taiwan, R.O.C.

E-mail:mjhou@mail.cmu.edu.tw

Key words: MJ-56, metastasis, EGFR, c-Met, HT29 colorectal cancer cells suggest a potential role of MJ-56 on therapy of colorectal cancer metastasis.

\section{Introduction}

Colorectal cancer is a commonly diagnosed cancer and one of the leading causes of cancer death in the world $(1,2)$. Metastasis is one of the major causes of deaths of colorectal cancer (3). Metastasis occurs through a stepwise process that starts when cancer cells segregate from a primary tumor, migrate across blood vessel walls then into the blood stream and invade into tissue (4-6). Finally, cancer cells disperse throughout new tissues to survive in the new ectopic sites and generate malignant tumors $(1-3,6)$.

Matrix metalloproteinases (MMPs), a group of secreted proteinases, play an important role in a variety of physiological and pathological processing colorectal cancer cell metastasis (7-10). MMPs degrade extracellular matrix (ECM) components in the basement membrane, increase cell invasion and metastasis in colorectal cancer cells (8-12). Many studies have shown that the functions of various metastatic molecules are modulated by MMPs (7,13-15). It has been reported that elevated MMP-2, MMP-7 and MMP-9 protein levels were detected in colorectal cancer. The correlation of MMP-2, MMP-7 and MMP-9 expression with invasion and metastasis has been demonstrated $(9,13,14,16,17)$. It is well established that receptor tyrosine kinase (RTK) activates the phosphatidylinositol 3-kinase (PI3K)/AKT and Ras-Rafmitogen-activated protein kinase (MAPK) pathways, resulting in the activation of eIF-4B, eIF-4E, eIF-4G and S6 and NF- $\kappa \mathrm{B}$ transcription factors (18-23). Those transcription factors are considered to be the regulator of MMP-2, MMP-7 and MMP-9 translation signaling $(24,25)$.

Quinazolinone derivatives have shown anti-malarial, antiinflammatory, anti-bacterial and antitumor activities in many studies $(26,27)$. Quinazolinone compounds have also been shown to possess antitumor activity to inhibit cell metastasis by downregulating the expression and activities of MMP-2 and MMP-9 in many cancer cell lines (28-30). Our previous study 
showed that 6-fluoro-(3-fluorophenyl)-4-(3-methoxyanilino) -quinazoline (LJJ-10) exhibits anti-metastatic effects in human osteosarcoma U-2 OS cells through targeting the insulin-like growth factor-I receptor (IGF-IR) (29). The 2-(3-ethoxyphenyl)-6-pyrrolidinylquinazolinone) (MJ-33) exhibits anti-metastatic effects in human prostate carcinoma DU145 cells via decreased protein levels of MAPKs (mitogen-activated protein kinases), AKT, AP-1 and $\mathrm{NF}-\kappa \mathrm{B}$, resulting in the inhibition of MMP-2 and MMP-9 (28). Receptor tyrosine kinases have been indicated as promising molecular targets for cancer therapy (31-34). The c-Met, a receptor tyrosine kinase, is overexpressed and/or mutated in a variety of tumor cells $(31,35)$. Abnormal activation of c-Met signaling can lead to angiogenesis, proliferation, invasion and metastasis (36-38). EGFR, epidermal growth factor receptor, functions with a vital role in colorectal cancer initiation and progression $(39,40)$. Although c-Met and EGFR are recognized as important therapeutic targets for the treatment of malignancies, the inhibitory effect of c-Met and EGFR in human colorectal cancer cells remains unclear. In the present study, we investigated the anti-metastatic activity of MJ-56 (6-pyrrolidinyl-2-(3-bromostyryl)quinazolin-4-one) (Fig. 1), a novel synthesized quinazolinone derivate and the anti-metastatic pathways of MJ-56 in the human colorectal cancer cell line HT29.

\section{Materials and methods}

Chemicals and reagents. MJ-56 was designed and synthesized by Mann-Jen Hour from China Medical University, Taichung, Taiwan (Fig. 1). Antibodies against MMP-1, MMP-2, MMP-7, MMP-9, MMP-10, TIMP-1, TIMP-2, p85-PI3K, p110-PI3K, p65 NF- $\kappa$ B, PCNA, p38, GAPDH (Santa Cruz Biotechnology, Inc.; Santa Cruz, CA, USA), EGFR, p-EGFR (Tyr1173), c-Met, p-S6 (Ser240/244), p-Mnk1 (Thr197/202), p-eIF4E (Ser209), p-eIF4G (Ser1108), p-eIF4B (Ser422), p-JNK (Thr183/Tyr185), JNK, p-p38 (Thr183/Tyr185), p-ERK (Thr202/Tyr204), ERK, p-mTOR (Ser2448), mTOR, p-AKT (Ser473), AKT (Cell Signaling; Danvers, MA, USA) were obtained from the indicated vendors. Rabbit anti-mouse IgG (HRP) antibody, goat anti-rabbit IgG (HRP) antibody, donkey anti-goat IgG (HRP) antibody and FITC-conjugated goat anti-mouse antibody were obtained from Santa Cruz Biotechnology, Inc. Propidium iodide (PI) was from Sigma-Aldrich (St. Louis, MO, USA). DMEM medium, fetal bovine serum (FBS), L-glutamine, penicillin-streptomycin and trypsin-EDTA were purchased from Invitrogen Life Technologies (Carlsbad, CA, USA).

Cell culture. Human colorectal cancer cell line, HT29, was purchased from Food Industry Research and Development Institute (FIRDI, Hsinchu, Taiwan). HT29 cells were cultured in DMEM medium supplemented with $10 \%$ of fetal bovine serum, $100 \mathrm{U} / \mathrm{ml}$ penicillin, $100 \mu \mathrm{g} / \mathrm{ml}$ streptomycin and $2 \mathrm{mM}$ glutamine and incubated at $37^{\circ} \mathrm{C}$ in a humidified chamber with $5 \% \mathrm{CO}_{2}(24)$.

Wound healing assay. HT29 cells (cell density: 1×106 cells/ well) were seeded 6 -well plate and grown to $90 \%$ of confluence. The next day, cells were scratched with a yellow tip and treated with various concentrations of MJ-56 (0, 5, 10 and
$15 \mu \mathrm{M}$ ) in DMEM serum-free medium for $24 \mathrm{~h}$. The cells were captured and relative cell migration was calculated. All treatments were in duplicate and three independent experiments were performed $(4,28,30)$.

Cell invasion assay. The membrane of transwell insert was rinsed with PBS and coated with Matrigel (BD Matrigel ${ }^{\mathrm{TM}}$ Invasion chamber). Cells were seeded into the chamber of the insert at a density of $2.5 \times 10^{4}$ cells $/ \mathrm{ml}$ and incubated with $0.5 \mathrm{ml}$ of complete DMEM medium in the transwell. HT29 cells were treated with various concentrations of MJ-56 (0, 5, 10 and $15 \mu \mathrm{M})$ for $24 \mathrm{~h}$ and cells inside the chamber were removed. Invaded cells were fixed with $4 \%$ formaldehyde in PBS and stained with $0.1 \%$ of hematoxylin (Sigma-Aldrich), captured and the number of invaded cells were counted and used for the calculation of inhibitory rate $(28,30)$.

Gelatin zymography analysis. HT29 cells (cell density: $1 \times 10^{6}$ cells/well) were seeded into 6-well plate and grew for $24 \mathrm{~h}$. Cells were treated with various concentrations of MJ-56 $(0,5,10$ and $15 \mu \mathrm{M})$ in serum-free DMEM medium for $24 \mathrm{~h}$. Culture medium was collected and spun at $1000 \mathrm{x} g$ for $10 \mathrm{~min}$ at $4^{\circ} \mathrm{C}$. Supernatant was collected and $5 \mu \mathrm{g}$ of total protein was mixed with $2 \mathrm{X}$ sample buffer $(0.125 \mathrm{M}$ Tris- $\mathrm{HCl}, 4 \% \mathrm{SDS}$, $20 \%$ glycerol, $0.01 \%$ bromophenol blue) and separated in an $8 \%$ SDS-polyacrylamide gel with $1 \%$ gelatin. Gel was treated with $2.5 \%$ Triton-X-100 at room temperature for $30 \mathrm{~min}$ to remove SDS, incubated in Zymogen developing buffer $(50 \mathrm{mM}$ Tris, pH 7.5, $200 \mathrm{mM} \mathrm{NaCl}, 5 \mathrm{mM} \mathrm{CaCl}_{2}, 0.02 \%$ Brij-35; Bio-Rad Laboratories; Hercules, CA, USA) at room temperature for $30 \mathrm{~min}$, then refreshed with Zymogen developing buffer and incubated at $37^{\circ} \mathrm{C}$ for $24 \mathrm{~h}$. Gel was rinsed with water once and stained with $0.5 \%$ of Coomassie blue R-250 (0.5\% Coomassie blue R-250, 50\% methanol and $10 \%$ acetic acid) for $2 \mathrm{~h}$ and de-stained in de-staining solution (50\% methanol and $10 \%$ acetic acid) until clear zones were visualized $(28,30)$.

Preparation of whole cell lysate and nuclear lysate. HT29 cells were treated with various concentrations of MJ-56 for the given time and cells were harvested for the preparation of whole cell lysate using iced-cold RIPA buffer (1\% NP-40, $50 \mathrm{mM}$ Tris-base, $0.1 \%$ SDS, $0.5 \%$ deoxycholic acid, $150 \mathrm{mM} \mathrm{NaCl}, \mathrm{pH} 7.5)$ supplemented with the protease inhibitors including phenylmethanesulfonyl fluoride $(10 \mathrm{mg} /$ $\mathrm{ml})$, leupeptin $(17 \mathrm{mg} / \mathrm{ml})$ and sodium orthovanadate $(10 \mathrm{mg} /$ $\mathrm{ml})$. Cells were vortexed briefly and incubated in ice for $30 \mathrm{~min}$ and cell lysate was collected by a spin at $12,000 \mathrm{x} \mathrm{g}$ at $4^{\circ} \mathrm{C}$ for $10 \mathrm{~min}$. Nuclear extracts were obtained by using the NE-PER Nuclear and Cytoplasmic Extraction kit (Thermo Scientific; Rockford, IL, USA). The resulting nuclear pellet was re-suspended in nuclear extraction buffer $\left(1.5 \mathrm{mM} \mathrm{MgCl}_{2}\right.$, $10 \mathrm{mM}$ HEPES, pH 7.9, 0.1 mM EDTA, $0.5 \mathrm{mM}$ dithiothreitol, $0.5 \mathrm{mM}$ phenylmethanesulfonyl fluoride, $25 \%$ glycerol and $420 \mathrm{mM} \mathrm{NaCl}$ ) and incubated in ice for $20 \mathrm{~min}$, then spun at $14,000 \mathrm{x} \mathrm{g}$ for $5 \mathrm{~min}$. The supernatant, the soluble nuclear fraction, was collected and used for EMSA analysis of NF- $\kappa \mathrm{B}$

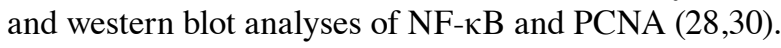

Electrophoretic mobility shift assay (EMSA). HT29 cells were seeded at a density of $1 \times 10^{6}$ cells $/ \mathrm{ml}$ the day before treatment. 
Cells were then treated with $15 \mu \mathrm{M}$ of MJ-56 for 0 and $4 \mathrm{~h}$. Nuclear extracts were prepared using NE-PER Nuclear and Cytoplasmic Extraction kit (Thermo Scientific) and soluble nuclear fraction was prepared as described above. The protein concentrations were determined by using Bio-Rad Protein Assay Dye Reagent Concentrate (Bio-Rad). Biotin end-labeled oligonucleotide corresponding to consensus NF- $\kappa \mathrm{B}$ binding site (5'-GATCCAGGGGACTTTCCCTAGC-3') was prepared with the LightShift Chemiluminescent EMSA kit (Thermo Scientific) and used as the probe. The $5 \mu \mathrm{g}$ of nuclear extract was incubated with biotin end-labeled duplex DNA, electrophoresed on a $6 \%$ polyacrylamide native gel, transferred to a positive nylon membrane, UV cross-linked and incubated with streptavidin-HRP and signals were developed by ECL kit (Millipore) $(28,30)$.

Western blot analysis. Whole cell lysate and nuclear extract were isolated from treated cells as described above, separated by sodium dodecyl sulfate-polyacrylamide gel electrophoresis (SDS-PAGE) and electro-transferred to a nitrocellulose membrane using the iBot Dry Blotting System (Invitrogen Life Technologies). The transferred membranes were incubated in blocking buffer (5\% non-fat milk in Tris-buffered saline/Tween-20) for $1 \mathrm{~h}$ and incubated with primary antibody in blocking buffer at $4^{\circ} \mathrm{C}$ overnight. Membranes were washed with Tris-buffered saline/Tween-20 three times for $10 \mathrm{~min}$ and incubated with HRP-conjugated secondary antibody for $1 \mathrm{~h}$. Protein signals were revealed by using ECL kit (Millipore) and exposed to Kodak Bio-MAX MR film (Estman Kodak, Rochester, NY, USA) $(28,30)$.

Immuno-fluorescent staining. HT29 cells were seeded onto polylysine-coated slides (cell density: $1 \times 10^{5}$ cells $/ \mathrm{ml}$ ) the day before staining. On the next day, cells were treated with $15 \mu \mathrm{M}$ of MJ-56 for $4 \mathrm{~h}$, fixed with $4 \%$ formaldehyde in PBS, permeabolized with $0.1 \%$ Triton X-100 for 30 min, blocked with $10 \%$ normal goat serum for $30 \mathrm{~min}$ and probed with primary antibody p65 NF- $\kappa \mathrm{B}$ at $4^{\circ} \mathrm{C}$ overnight. Then, cells were stained for FITC-conjugated goat anti-mouse secondary antibodies for $1 \mathrm{~h}$, washed and mounted in Shandan mounting medium. The images were captured using a fluorescence microscopy (41).

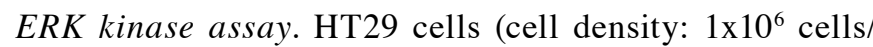
$\mathrm{ml}$ ) were treated with $15 \mu \mathrm{M}$ of MJ-56 for $0-4 \mathrm{~h}$ and ERK kinase activity was analyzed using p44/42 MAP Kinase assay kit obtained from Cell Signaling (\#9800). The p44/42 MAP Kinase was immuno-precipitated from cell lysate of treated cells with anti-phospho-p44/42 MAPK (Thr202/Tyr204) antibody and mixed with Elk-1 fusion protein and ATP in kinase buffer (25 mM Tris-HCl, pH 7.5, $5 \mathrm{mM} \beta$-glycerophosphate, $2 \mathrm{mM}$ dithiothreitol (DTT), $0.1 \mathrm{mM} \mathrm{Na} \mathrm{VO}_{4}, 10 \mathrm{mM} \mathrm{MgCl}$ ) and incubated at $37^{\circ} \mathrm{C}$ for $30 \mathrm{~min}$. The reaction was stopped by boiling in sample buffer and subjected to western blot analysis using anti-phospho-Elk-1 (Ser 383) antibody. The intensity of protein bands was quantified by NIH ImageJ and the intensity of protein band from untreated cells was set as $100 \%$ and the intensity of other treatments was calculated accordingly. Shown was the average data from three independent experiments $(42,43)$.

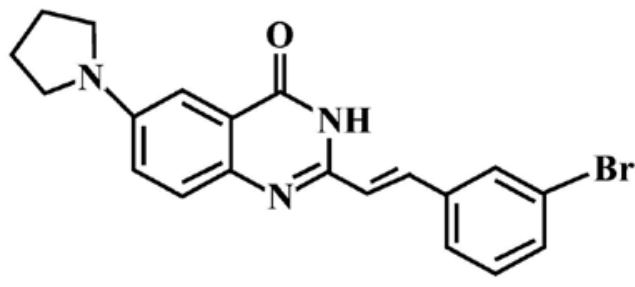

\section{$\underline{\text { MJ-56 }}$}

\section{6-pyrrolidinyl-2-(3-bromostyryl)quinazolin-4-one}

Figure 1. The chemical structure of MJ-56 (6-pyrrolidinyl-2- (3-bromostyryl) quinazolin-4-one).

AKT kinase assay. HT29 cells (cell density: $1 \times 10^{6}$ cells $/ \mathrm{ml}$ ) were treated with $15 \mu \mathrm{M}$ of MJ-56 for $0-4 \mathrm{~h}$ and AKT kinase activity was analyzed using AKT Kinase Assay kit from Cell Signaling (\#9840). AKT was precipitated from cell lysate of treated cells with anti-AKT antibody and mixed with GSK-3 fusion protein and ATP in kinase buffer $(25 \mathrm{mM}$ Tris- $\mathrm{HCl}$, $\mathrm{pH} 7.5,5 \mathrm{mM} \beta$-glycerophosphate, $2 \mathrm{mM}$ dithiothreitol (DTT), $0.1 \mathrm{mM} \mathrm{Na} \mathrm{VO}_{4}, 10 \mathrm{mM} \mathrm{MgCl}$ ) and incubated at $30^{\circ} \mathrm{C}$ for $30 \mathrm{~min}$. The reaction was stopped by boiling in sample buffer and subjected to western blot analysis using anti-phosphoGSK3 (Ser219) antibody. The intensity of protein bands was quantified by NIH Image J and the intensity of protein band from untreated cells was set as $100 \%$ and the intensity of other treatments was calculated accordingly. The average of the data was shown from three independent experiments (44).

Tyrosine kinase assay. HT29 cells (cell density: 1x106 cells/ $\mathrm{ml}$ ) were treated with $15 \mu \mathrm{M}$ of MJ-56 for $0-4 \mathrm{~h}$ and Tyrosine kinase activity was analyzed using Tyrosine Kinase assay kit from Upstate (\#17-315) (EMD Millipore Corp., Billerica, MA, USA). Cell lysate was incubated with biotinylated poly (Glu4-Tyr) peptide as the substrate and ATP in a kinase buffer containing $\mathrm{Mn}^{2+} / \mathrm{Mg}^{2+}$ as the co-factors. Tyrosinated substrate was recognized by anti-phosphotyrosine-HRP and detected by enzyme-linked immunosorbent assay (ELISA). The kinase activity from untreated cells was set as $100 \%$ and the kinase activity of other treatments was calculated accordingly. Shown was the average data from three independent experiments (45).

Statistical analysis. The statistical results were expressed as the mean \pm SEM of triplicate samples. The difference between groups was analyzed by One-way ANOVA followed by paired two-tailed Student's t-test and ${ }^{*} \mathrm{P}<0.05$ was taken as significant.

\section{Results}

MJ-56 inhibits migration and invasion of HT29 cells. Quinazolinone derivatives have been shown to possess antitumor activities $(26,30,32)$. To obtain more effective drugs for cancer treatment, we have chemically modified the quinazolinone derivatives. MJ-56, a novel quinazolinone derivative, was synthesized (Fig. 1) and determined its antitumor activity by assaying cell migration and invasion in HT29 colorectal carcinoma cells. HT29 cells were treated with various concen- 

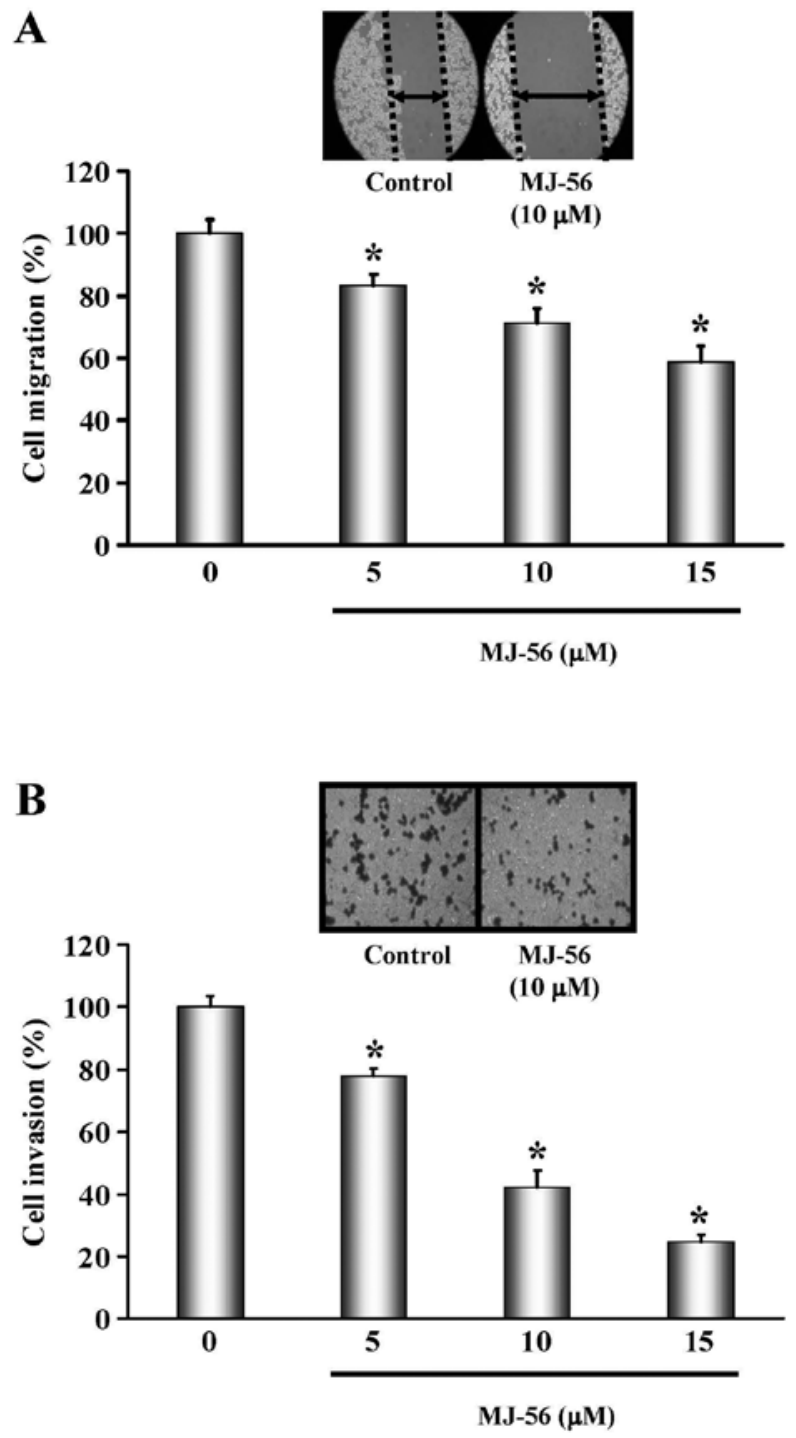

Figure 2. MJ-56 inhibits the migration and invasion of HT29 cells (A) Migration of cells in a monolayer was measured using the scratch wound healing assay. Cells were seeded in a 6-well plate. After $24 \mathrm{~h}$ of growth, cells were scratched with a pipette tip and incubated with FBS free DMEM medium containing with or without MJ-56 $(0,5,10$ and $15 \mu \mathrm{M})$ for $24 \mathrm{~h}$. Cell migration was calculated. Representative images are shown in the top panel. (B) Cell invasion was detected by Matrigel. Cells were seeded in a 24-well plate and incubated with FBS free DMEM medium with or without MJ-56 $(0,5,10$ and $15 \mu \mathrm{M})$ for $24 \mathrm{~h}$. After $24 \mathrm{~h}$ of growth, cells penetrated through the Matrigel to the lower surface of the filter were stained with crystal violet and counted under a light microscope at $\mathrm{x} 200$. Representative images are shown in the top panel. Each point is mean \pm SD of three experiments. * $\mathrm{p}<0.05$, indicates a significant difference from the control.

trations $(0,5,10$ and $15 \mu \mathrm{M})$ of MJ-56 for $24 \mathrm{~h}$. The effect of MJ-56 on the cell migration was determined by the scratch assay. As shown in Fig. 2A, migration of HT29 cells was gradually impeded with an increase in the concentrations of MJ-56. Cell invasion is a critical step during cancer metastasis. To characterize whether MJ-56 inhibits cell invasion, HT29 cells were treated with various concentrations $(0,5,10$ and $15 \mu \mathrm{M})$ of MJ-56 and the effects of MJ-56 on cell invasion were examined by the Matrigel-coated transwell assay. MJ-56 inhibited invasion of HT29 cells in a concentration-dependent manner. The inhibitory rate was calculated as the percentage of $21.88,54.24$ and $75.58 \%$ for 5,10 and $15 \mu \mathrm{M}$ of MJ-56treated cells, respectively (Fig. 2B).

MJ-56 inhibits the expression and enzyme activity of matrix metalloproteinases and increases the expression of metalloproteinase inhibitors TIMP-1 and TIMP-2. During cancer metastasis, matrix metalloproteinases (MMPs) are indispensible for the degradation of extracellular matrix, an important step for cancer invasion. Due to the inhibitory effects of MJ-56 on cell migration and invasion, we subsequently determined whether MJ-56 may block the expression and enzymatic activity of MMPs. HT29 ells were treated with various concentrations of MJ-56 (0, 5, 10 and $15 \mu \mathrm{M})$ for $24 \mathrm{~h}$ and cells were harvested for western blot analyses. MJ-56 suppressed the expression of matrix metalloproteinases MMP-2, MMP-7, MMP-9 and MMP-10 in a concentration-dependent manner (Fig. 3A). However, the expression of MMP-1 appeared not to be affected by MJ-56 treatment (top row, Fig. 3A). In contrast, TIMP-1 and TIMP-2 are metalloproteinase inhibitors that can block the enzymatic activities of MMPs, thereby inhibiting cancer invasion. The expression of TIMP-1 and TIMP-2 was elevated with the increase in the concentrations of MJ-56 $(0-15 \mu \mathrm{M})$ in HT29 cells (Fig. 3B). Concomitantly, MJ-56 inhibited the enzymatic activities of MMP-2 and MMP-9 by gelatin zymography analysis (Fig. 3C). The MMP-9 activity was significantly decreased at $5 \mu \mathrm{M}$ of MJ-56 and the inhibition of MMP-2 activity was observed at $15 \mu \mathrm{M}$ of MJ-56. Our data revealed that MJ-56 may upregulate the expression of TIMP-1 and TIMP-2, downregulate the expression of MMP-2, $-7,-9,-10$ and reduce the enzymatic activities of MMP-2 and MMP-9 in HT29 cells, which might be responsible for the concentration-dependent inhibition of cell invasion by MJ-56.

MJ-56 inhibits tyrosine phosphorylation of EGFR and expression of $c$-MET. It has been reported that the activation of autophosphorylation on the receptor tyrosine kinase EGFR can activate the downstream signaling events to increase the expression of MMP family proteins such as MMP-2, MMP-7 and MMP-9, contributing to metastasis and invasion of colorectal cancers (46-48). We determined the effects of MJ-56 on the inhibition of tyrosine kinase activity. HT29 cells were treated with $15 \mu \mathrm{M}$ of MJ-56 for $0-4 \mathrm{~h}$ and tyrosine kinase activity was examined by colorimetric detection of protein tyrosine kinase activity. As shown in Fig. 4A, MJ-56 reduced the tyrosine kinase activity of treated cells in a time-dependent manner, with $>60 \%$ of inhibition after $1 \mathrm{~h}$ of treatment. As tyrosine kinase activity was inhibited by MJ-56, we then determined whether MJ-56 acts on the inhibition of receptor tyrosine kinase activity of EGFR, a receptor protein that undergoes auto-phosphorylation via its intrinsic tyrosine kinase activity after activation. HT29 cells were treated with $15 \mu \mathrm{M}$ of MJ-56 at various time points $(0,0.5$ and $1 \mathrm{~h})$ and tyrosine phosphorylation and expression of EGFR was examined by western blotting. As shown in Fig. 4B, MJ-56 inhibited the tyrosine phosphorylation of EGFR and c-Met in a timedependent fashion, while the protein level of EGFR remained unchanged (second row, Fig. 4B). Given that MJ-56 inhibited the tyrosine kinase activity of receptor tyrosine kinase EGFR, we inferred that MJ-56 would be able to inhibit other receptor tyrosine kinases such as c-Met. MJ-56 also decreased the 

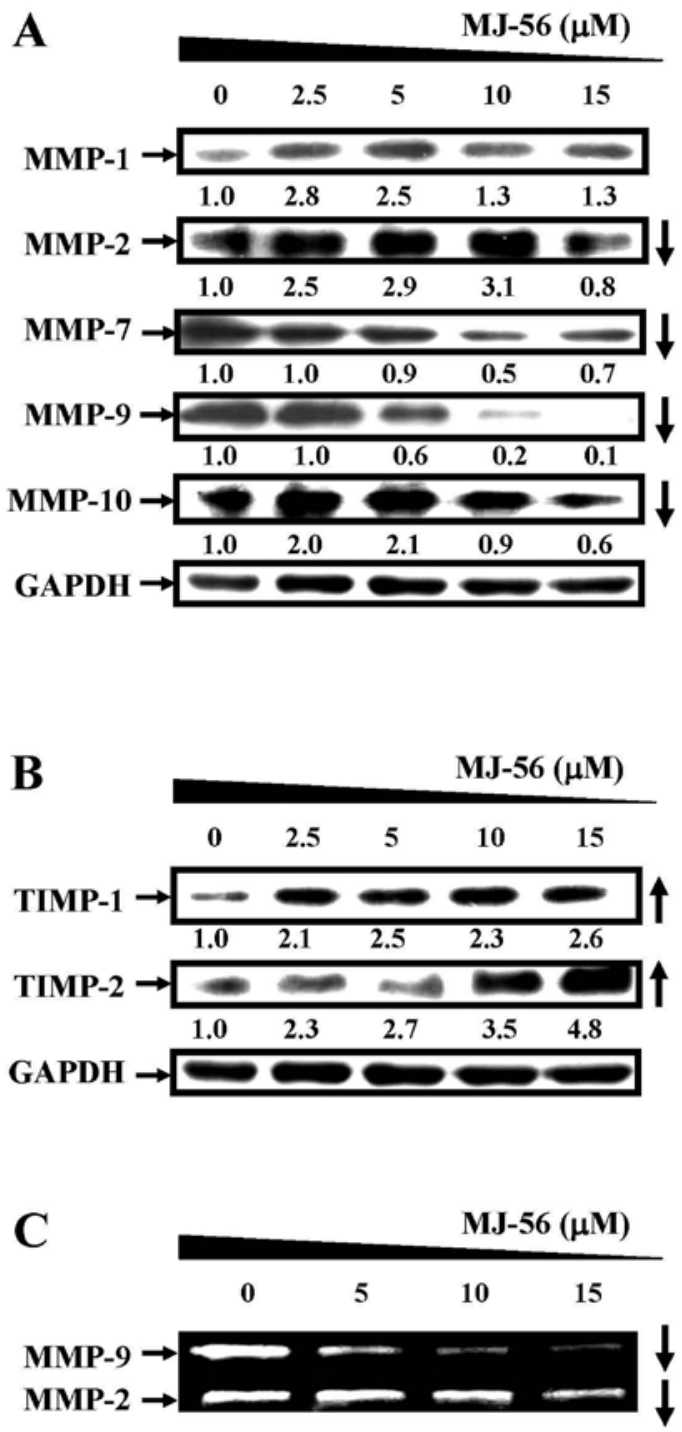

Figure 3. MJ-56 regulates MMPs and TIMPs. (A) The protein expression levels of matrix metalloproteinases MMP-2, MMP-7, MMP-9 and MMP-10 were downregulated in the presence of MJ-56 by western blot analysis. Protein fold changes were normalized to the endogenous GAPDH control. (B) The protein expression levels of metalloproteinase inhibitors TIMP-1 and TIMP-2 were upregulated in the presence of MJ-56 by western blot analysis. Protein fold changes were normalized to the endogenous GAPDH control (C) Cells were treated with various concentrations $(0,5,10$ and $15 \mu \mathrm{M})$ of MJ-56 for $24 \mathrm{~h}$. MMP-2 and MMP-9 activities were quantified by densitomeric analysis. The densitomeric data were expressed as mean $\pm \mathrm{SD}$ of three independent experiments. ${ }^{*} \mathrm{p}<0.05$, indicates a significant difference from the control.

expression of receptor tyrosine kinase Met (third row, Fig. 4B). Our results suggest MJ-56 can inhibit receptor tyrosine kinase by targeting on the tyrosine kinase activity of EGFR and reducing the expression of c-Met receptor tyrosine kinase.

MJ-56 inhibits the ERK-mediated MAPK signaling pathway in HT29 cells. Aforementioned data showed that MJ-56 can inhibit the tyrosine kinase activity of EGFR and the expression of MMPs, thus we investigated whether the inhibition in the tyrosine kinase activity of EGFR and c-Met by MJ-56 results in the inhibition of downstream signaling, thereby reducing the expression of MMPs. We determined the effects

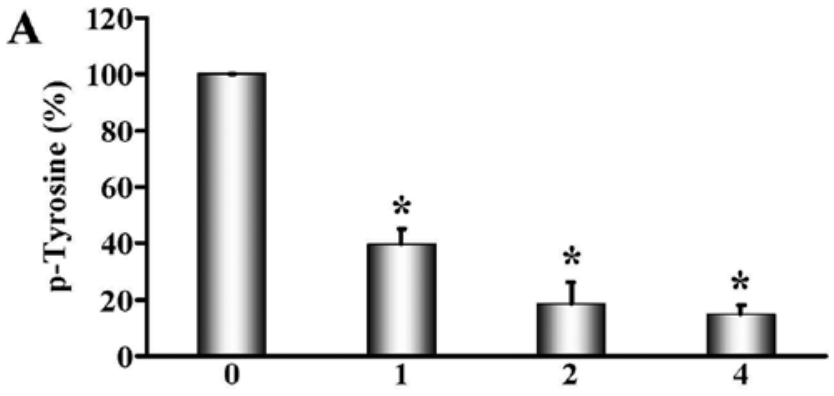

Time (h)

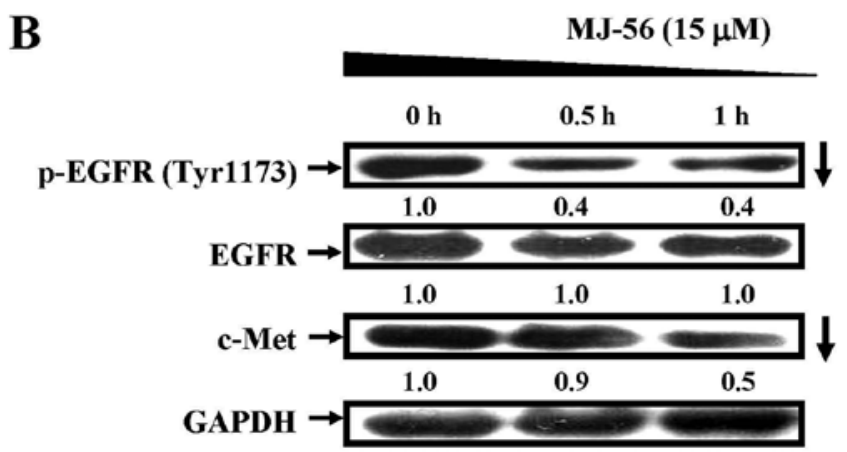

Figure 4. MJ-56 inhibits tyrosine kinase activity and suppresses protein expression levels of phosphorylated EGFR and c-MET. (A) Treatment of HT-29 with MJ-56 resulted in a decrease in tyrosine kinase activity by colorimetric detection of protein tyrosine kinase activity. The percentage of tyrosine kinase activity in MJ-56 treatment was compared with that in no treatment control. The percentage of tyrosine kinase activity was expressed as mean $\pm \mathrm{SD}$ of three independent experiments. "p $<0.05$, indicates a significant difference from the control. (B) The protein expression levels of p-EGFR (Tyr1173) and c-Met were downregulated in the presence of MJ-56 by western blot analysis. Protein fold changes were normalized to the endogenous GAPDH control.

of MJ-56 on the MAPK signaling pathway downstream of EGFR, which includes ERK1/2, c-Jun N-terminal kinase and p38 kinase signaling pathways. HT29 cells were treated with $15 \mu \mathrm{M}$ of MJ-56 at various time-points $(0,0.5,1,3$ and $6 \mathrm{~h})$. The expression and phosphorylation status of JNK, p38 and ERK were evaluated by western blot analyses. As shown in Fig. 5A, MJ-56 decreased the phosphorylation of ERK, while the expression of ERK remained largely unaffected. However, MJ-56 did not affect the activation of p38 and JNK. Since phosphorylation of ERK is required for the activation of its kinase activity, we examined whether the MJ-56-mediated inhibition of ERK phosphorylation will modulate ERK kinase activity. HT-29 cells were treated with $15 \mu \mathrm{M}$ of MJ-56 for $0-4 \mathrm{~h}$ and ERK kinase activity was assessed. The results showed that MJ-56 significantly inhibited ERK kinase activity in a timedependent manner (Fig. 5B). Thus, our data indicated that MJ-56 inhibits the ERK-mediated MAPK signaling pathway.

MJ-56 inhibits the PI3K/AKT/mTOR-dependent signaling pathway in HT29 cells. In addition to MAPK signaling pathway, PI3K/AKT/mTOR-dependent signaling pathway is also a downstream signaling pathway of EGFR. To examine the effects of MJ-56 on the PI3K/AKT/mTOR signaling pathway, HT29 cells were treated with $15 \mu \mathrm{M}$ of MJ-56 for different time (0-6 h), and western blot analyses were performed. The 
A
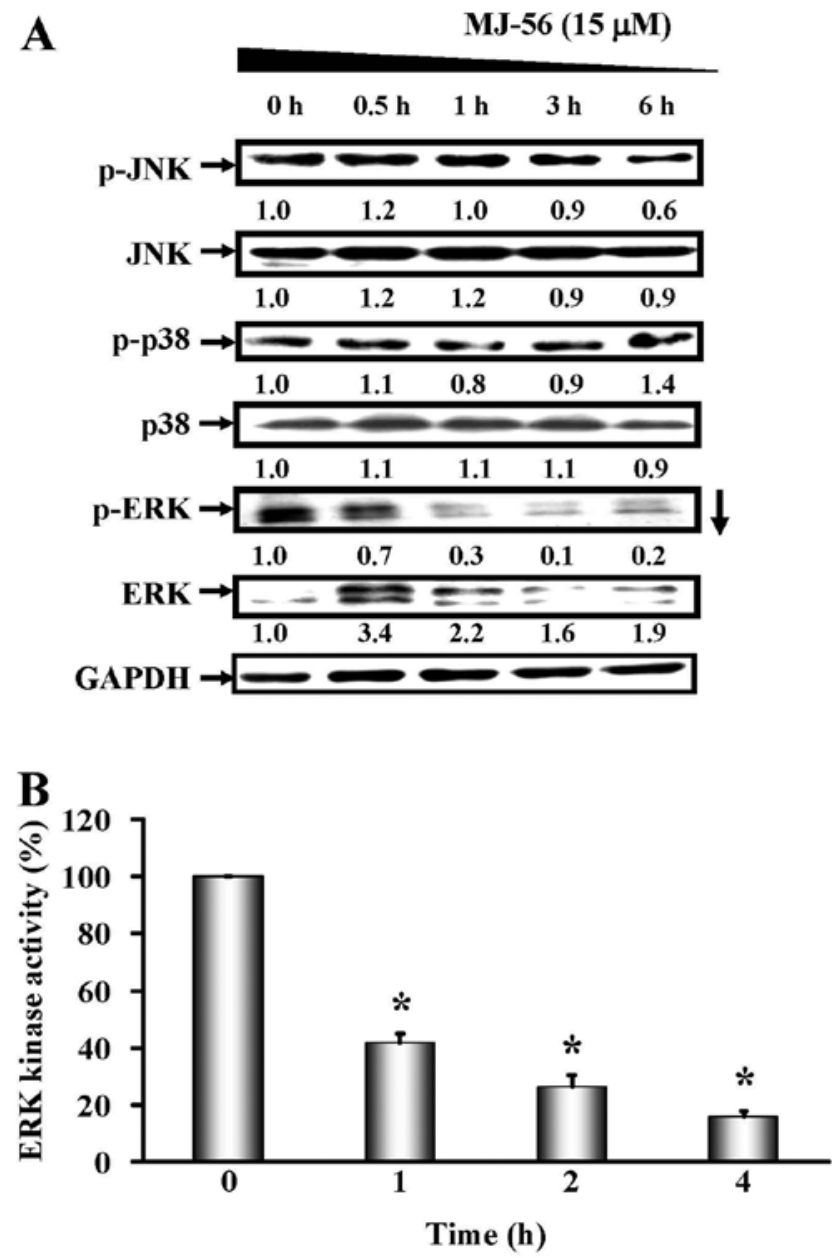

Figure 5. MJ-56 blocks ERK-mediated MAPK signaling pathway in HT29 cells. (A) Cells were harvested at $0,0.5,1,3$ and $6 \mathrm{~h}$ after MJ-56 treatment. The protein levels of p-JNK, JNK, p-p38, p38, p-ERK and ERK were analyzed by western blotting. Protein fold changes were normalized to the endogenous GAPDH control. (B) Cells were harvested at $0,1,2$ and $4 \mathrm{~h}$ after MJ-56 treatment. Cell lysates were immuno-precipitated with anti-phosphop44/42 MAPK (Thr202/Tyr204) antibody and assessed ERK kinase activity by measuring phosphorylation of Elk-1. ERK kinase activity in MJ-56 treatment was compared with that in no treatment control. ERK kinase activity was expressed as mean $\pm \mathrm{SD}$ of three independent experiments. ${ }^{*} \mathrm{p}<0.05$, indicates a significant difference from the control.

results showed that the expression of PI3K (p85), the regulatory subunit of PI3K, appeared not to be affected (top row, Fig. 6A). MJ-56 decreased the expression of PI3K (p110), the catalytic subunit of PI3K kinase (second row, Fig. 6A). In addition, MJ-56 reduced the phosphorylation of AKT and mTOR, while the expression of AKT and mTOR seemed not to be altered (Fig. 6A). As phosphorylation of AKT is important for its kinase activity, the reduction in phosphorylation of AKT by MJ-56 implies that the kinase activity of AKT will be affected. As shown in Fig. 6B, MJ-56 indeed inhibited the enzymatic activity of AKT kinase in a time-dependent manner. Therefore, our results suggested that MJ-56 is able to inactivate the PI3K/ AKT/mTOR-dependent signaling pathway in HT29 cells. To evaluate whether MJ-56 inhibits the downstream proteins of ERK-mediated MAPK and PI3K/AKT/mTOR signaling pathways, HT29 cells were treated with $15 \mu \mathrm{M}$ of MJ-56 for 0 to $6 \mathrm{~h}$ and the phosphorylation of S6, Mnk1, eIF-4B, eIF-4E and
A
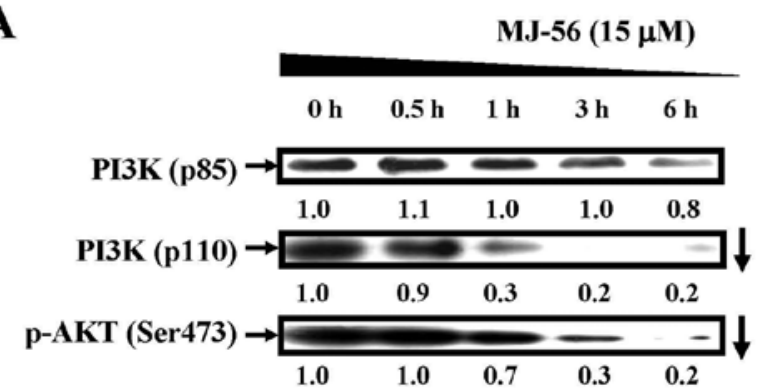

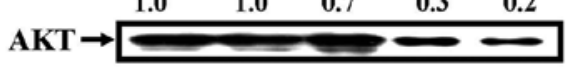

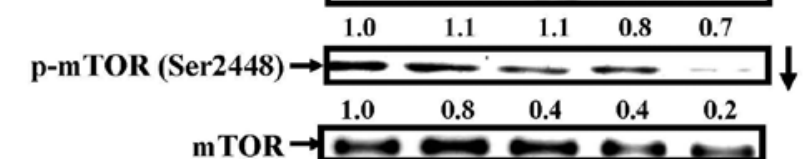

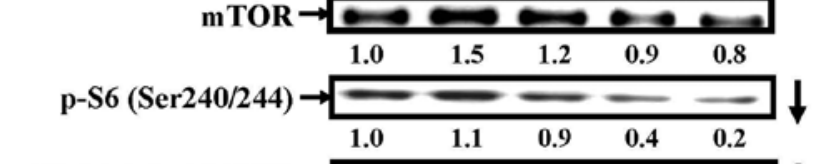

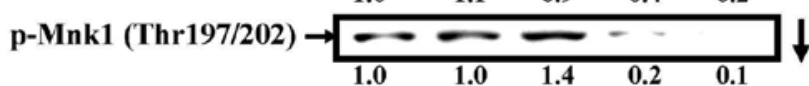

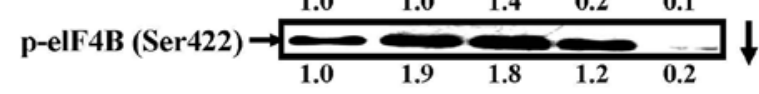

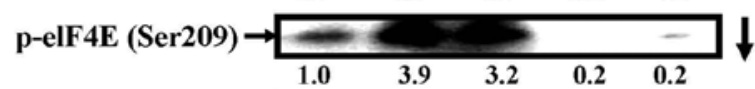

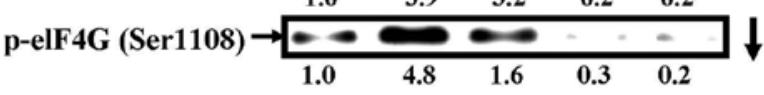

GAPDH $\rightarrow=2$

B

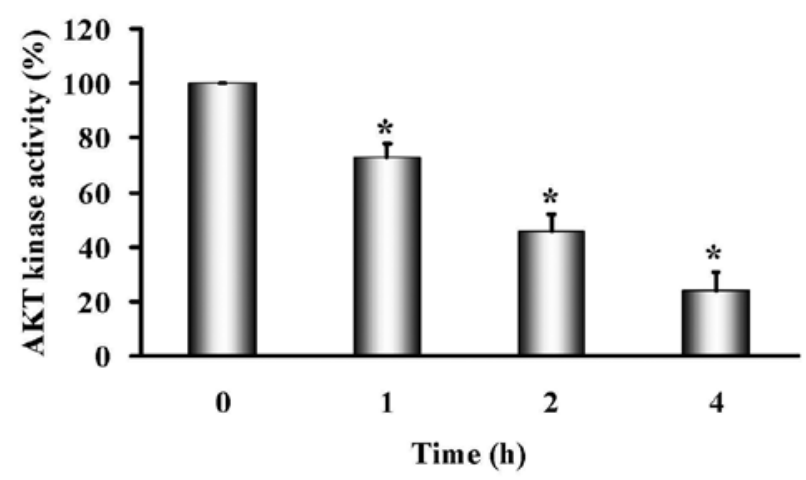

Figure 6. MJ-56 modulates PI3K/AKT/mTOR-dependent signaling pathway in HT29 cells. (A) Cells were harvested at 0, 0.5, 1, 3 and $6 \mathrm{~h}$ after MJ-56 treatment. The protein levels of p110-PI3K, p85-PI3K, p-AKT (Ser473), AKT, p-mTOR (Ser2448), mTOR, p-S6 (Ser240/244), p-Mnk1 (Thr197/202), p-eIF4B (Ser422), p-eIF4E (Ser209) and p-eIF4G (Ser1108) were analyzed by western blotting. Protein fold changes were normalized to the endogenous GAPDH control. (B) Cells were harvested at $0,1,2$ and $4 \mathrm{~h}$ after MJ-56 treatment. Cell lysates were immunoprecipitated with anti-AKT antibody and assessed AKT kinase activity by measuring phosphorylation of GSK-3. AKT kinase activity in MJ-56 treatment was compared with that in no treatment control. AKT kinase activity was expressed as mean $\pm \mathrm{SD}$ of three independent experiments. ${ }^{*} \mathrm{p}<0.05$, indicates a significant difference from the control.

eIF-4G was examined by western blot analyses. As shown in Fig. 6A, MJ-56 treatment led to a time-dependent inhibition in the phosphorylation of S6, Mnk1, eIF-4B, eIF-4E and eIF-4G, although MJ-56 treatment resulted in different inhibition kinetics for each protein. Our data showed that MJ-56 inhibits the phosphorylation of Mnk1 and elF-4E, downstream targets 
A

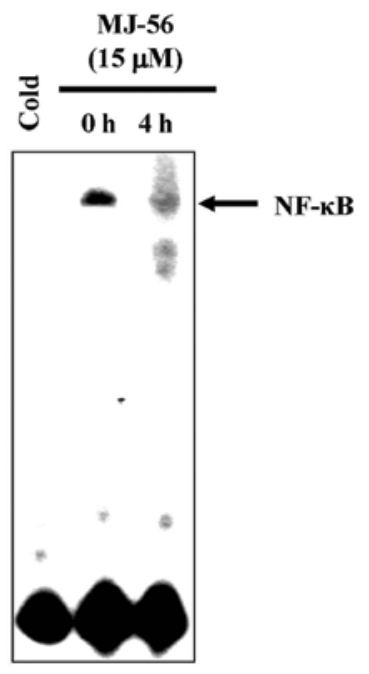

B

Nuclear fractionation

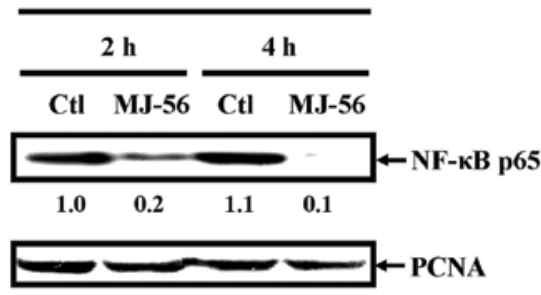

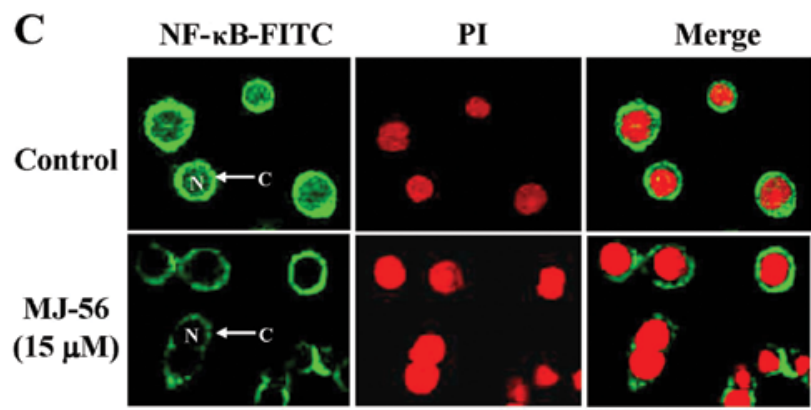

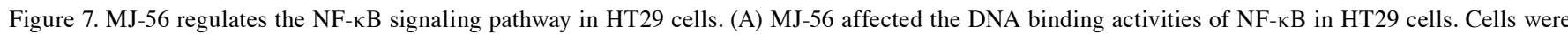
treated with $15 \mu \mathrm{M}$ of MJ-56 for $4 \mathrm{~h}$. Nuclear extracts were prepared and analyzed for NF-kB DNA binding activity using biotin labeled oligonucleotides containing the NF- $\mathrm{KB}$ consensus sequences. EMSA assay was performed as described in Materials and methods. Lane 1, unlabeled consensus oligonucleotides; lane 2, control; lane 3,15 $\mu \mathrm{M}$ of MJ-56 for $4 \mathrm{~h}$. Excess free probe is indicated at the bottom. Results from three repeated and separate experiments were similar. (B) NF-кB expression was examined by western blotting. Cells were treated with $15 \mu \mathrm{M}$ of MJ-56 for 2 and 4 h. Protein fold changes were normalized to the endogenous PCNA control. (C) NF- $\kappa \mathrm{B}$ localization was examined by immunostaining. Cells treated with $15 \mu \mathrm{M}$ of MJ-56 for $4 \mathrm{~h}$ were immunostained with FITC-conjugated anti-p65 antibody and propidium iodide (PI). $\mathrm{N}$ represents nucleus and C represents cytoplasm.

of ERK-mediated MAPK signaling pathway and S6, elF-4B, elF-4G, downstream targets of PI3K/AKT/mTOR signaling pathway, thereby disturbing translation initiation and protein synthesis at the ribosomes and hence reduced the expression of MMPs.

MJ-56 inhibits the NF- $\mathrm{B}$ signaling pathway in HT29 cells. It is known that PI3K/AKT signaling activates NF- $\kappa \mathrm{B}$. Activated $\mathrm{NF}-\kappa \mathrm{B}$ mobilizes to the nucleus, binds to the cognate site on the target promoters such as MMPs and turns on their gene expression. To clarify the effects of MJ-56 on the NF- $\kappa \mathrm{B}$ signaling pathway, HT-29 cells were treated with $15 \mu \mathrm{M}$ of MJ-56 for 0 and $4 \mathrm{~h}$. Translocation of $\mathrm{NF}-\kappa \mathrm{B}$ into the nucleus resulting in binding at NF- $\kappa \mathrm{B}$-responsive elements was accessed by electrophoretic mobility shift assay (EMSA). After HT-29 cells were treated with $15 \mu \mathrm{M}$ of MJ-56 for $4 \mathrm{~h}$, the amount of $\mathrm{NF}-\kappa \mathrm{B}$ that binds DNA dramatically blocked due to reduced nuclear translocation of NF- $\kappa \mathrm{B}$ (Fig. 7A). Nuclear extract was obtained from MJ-56-treated cells and assessed for western blot analyses of NF- $\kappa \mathrm{B}$ p65 (Fig. 7B). The results showed that the mobilization of NF- $\kappa \mathrm{B}$ into the nucleus was greatly reduced after $2 \mathrm{~h}$ of $\mathrm{MJ}-56$ treatment, as compared to that of control treatment. Consistently, immuno-fluorescent staining also showed that MJ-56 obstructs the translocation of $\mathrm{NF}-\kappa \mathrm{B}$

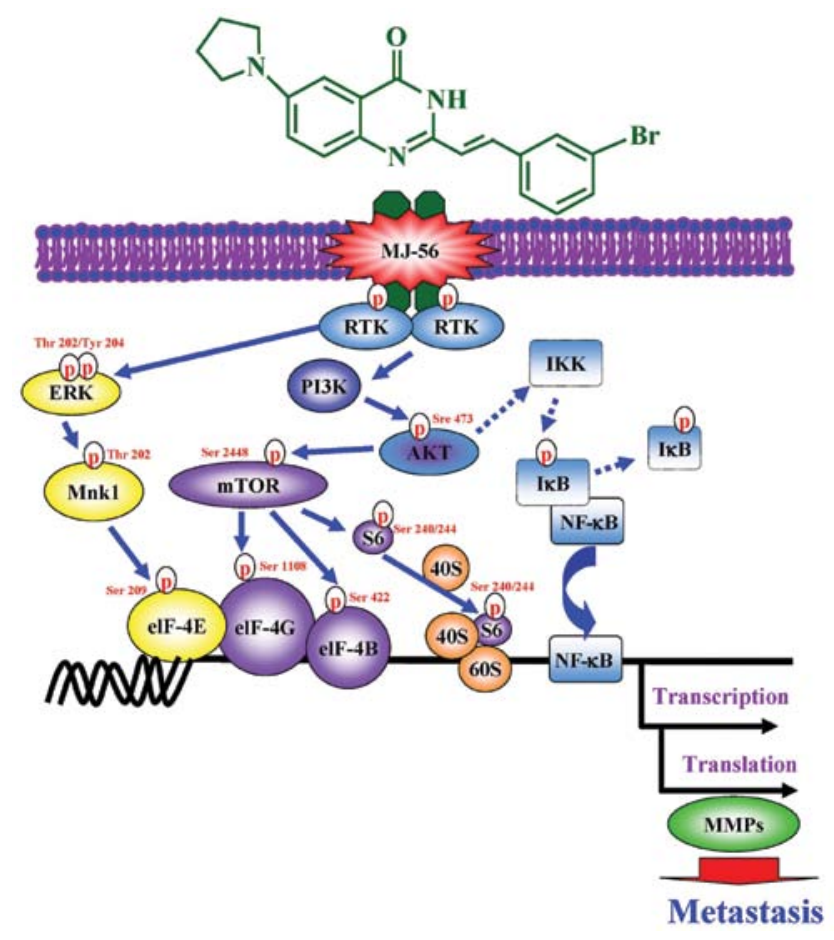

Figure 8. A model for the inhibitory effects of MJ-56 on invasion and migration in HT29. 
into the nucleus (Fig. 7C). These data suggest that MJ-56 interferes with the NF- $\mathrm{BB}$ signaling and therefore NF- $\kappa \mathrm{B}$ target genes such MMPs fail to be expressed.

\section{Discussion}

Previous studies demonstrated that quinazolinone derivatives not only exerts anticancer activity against many cancer cell lines in vitro and in vivo, but also induced cell death through apoptosis or autophagy and inhibited cell metastasis in cancer cells $(28,49-52)$. In our laboratory, a series of quinazolinone derivatives have been designed and synthesized and which are established to have anti-mitotic functions and anticancer activities in colorectal, lung, ovarian, oral, prostate and breast cancer, as well as in glioblastoma, osteosarcoma, melanoma and leukemia (28-30,49,50,53-55). The MJ-56 (6-pyrrolidinyl-2-(3-bromostyryl)quinazolin-4-one), one of the quinazolinone derivatives, exhibits the most potent cytotoxicity against colorectal cancer cell lines including HT29, COLO 205, SW480, SW620 and HCT116 (data not shown). In this study, our results provide detailed evidence that MJ-56 could modulate anti-cell migration and invasion effects and trigger MMPs activities by EGFR and c-Met pathways in HT29 human colorectal cancer cells. MMPs are known to be an accelerator of colorectal cancer cell invasion and metastasis and there are associated with the progression of tumorigenesis $(8,9,11,14,24,39,47,48)$. Our results demonstrated that MJ-56 can inhibit migration and invasion of HT29 cells (Fig. 2). MJ-56 reduced the protein levels of MMP-2, MMP-7, MMP-9, MMP-10 (Fig. 3A) as well as increased the protein levels of metalloproteinase inhibitors TIMP-1 and TIMP-2 by western blot analyses (Fig. 3B). MJ-56 also reduced the enzymatic activities of MMP-2 and MMP-9 by gelatin zymography assays (Fig. 3C).

Interference with receptor tyrosine kinase provides a novel approach in cancer therapy agents (56-59). Activation of the EGFR promotes processes responsible for cancer cell proliferation, angiogenesis, invasion, metastasis and inhibition of cell death (60-63). The agents targeting members of the human epidermal growth factor receptor (EGFR) have shown hopeful therapeutic efficacy $(58,64)$. Cetuximab (Erbitux) is a clinical success of selective EGFR inhibitor. Cetuximab improves the effectiveness of treatment for metastatic colorectal cancer (64-66). In this study, we demonstrated that MJ-56 is an EGFR and c-Met receptor tyrosine kinase inhibition agent using western blot and kinase assay analyses (Fig. 4). EGFR and c-Met are phosphorylated, which turn on downstream intracellular signaling cascades such as MAPK, PI3K/AKT/mTOR and NF- $\kappa B$ pathways. Our results suggested that inhibition of EGFR and c-Met receptor tyrosine kinase activity by MJ-56 might be suitable for novel targeted therapy of colorectal cancer.

MMP promoters have several regulatory motifs recognized by various proteins such as NF- $\mathrm{kB}, \mathrm{S} 6$, eIF-4B, eIF-4E and eIF-4G. The NF- $\kappa B$ protein binding to the MMP-2, MMP-7 and MMP-9 promoter is centrally involved in the induction of $M M P-2, M M P-7$ and $M M P-9$ gene expression associated with cell invasion $(24,28,30,46)$. On the other hand, the S6, eIF-4B, eIF-4E and eIF-4G binding to the MMP-7 promoter are centrally involved in the induction of
$M M P-7$ gene expression (24). Multiple pathways leading to activation of those transcription factors in cancer cells may contribute to MMP transcription and metastatic enhancement (67-72). MJ-56 reduced the protein levels of MMPs associated with inactivation of ERK (Fig. 5) and AKT (Fig. 6) as well as displayed inhibitory effects on NF- $\kappa \mathrm{B}, \mathrm{S} 6$, eIF-4B, eIF-4E and eIF-4G (Fig. 6). The inhibitory effect on nuclear entry of NF- $\kappa \mathrm{B}$ was consistent with less DNA binding activity of NF- $\mathrm{KB}$ (Figs. 7B and C). ERK is intricately involved in the expression of the components that are associated with MMP promoter induction through eIF-4E and its relation with Mnk1 phosphorylation (73-76). Activation of mTOR through the PI3K/AKT pathway leads to the phosphorylation of 4EBP1 and S6K1. The 4EBP1 phosphorylation inhibits the translation by interrupting the binding of eIF4E with eIF4G to form an eIF4F translation initiation complex that consists of eIF4A, 4G and 4E. Activated S6K1 causes phosphorylation of S6 and eIF4B, which, in turn, result in an increase in eIF4A RNA helicase activity $(24,77-82)$. We suggested that PI3K/AKT/ mTOR and ERK1/2 are the master regulators of translation initiation in MMPs. Inhibition of the ERK and PI3K/AKT pathways might have the potential of preventing cancer cell invasion and migration.

A model was proposed to elucidate molecular mechanisms by which MJ-56 suppresses cell migration, invasion and MMP activity in HT-29 human colorectal cancer cells (Fig. 8). In conclusion, MJ-56 might inhibit invasion and migration of HT29 cells through targeting the receptor tyrosine kinases, EGFR and c-Met. Thereafter, ERK and $\mathrm{PI} 3 \mathrm{~K} / \mathrm{AKT} / \mathrm{mTOR}$ signaling pathways are inactive. NF- $\mathrm{BB}$ signaling pathway is blocked, which leads to blocking of the transcription and translation of matrix metalloproteinases.

\section{Acknowledgements}

This study was supported by a research grant from the National Science Council of the Republic of China (NSC 97-2320-B-039-004-MY3). This study was also supported in part by grant from China Medical University (CMU101-S-27) awarded to J.-S. Yang.

\section{References}

1. Van Cutsem E, Dicato M, Arber N, et al: Molecular markers and biological targeted therapies in metastatic colorectal cancer: expert opinion and recommendations derived from the 11th ESMO/World Congress on Gastrointestinal Cancer, Barcelona, 2009. Ann Oncol 21 (Suppl 6): vi1-vi10, 2010.

2. Chu E: Colorectal cancer (CRC) continues to be a major public health problem in the United States and throughout the world. Cancer J 16: 195, 2010.

3. Hoogwater FJ, Nijkamp MW, Smakman N, et al: Oncogenic K-Ras turns death receptors into metastasis-promoting receptors in human and mouse colorectal cancer cells. Gastroenterology 138: 2357-2367, 2010.

4. Vallbohmer D, Kuramochi H, Shimizu D, et al: Molecular factors of 5-fluorouracil metabolism in colorectal cancer: analysis of primary tumor and lymph node metastasis. Int J Oncol 28: 527-533, 2006.

5. Jin K, Gao W, Lu Y, Lan H, Teng L and Cao F: Mechanisms regulating colorectal cancer cell metastasis into liver (Review). Oncol Lett 3: 11-15, 2012.

6. Ouellette JR, Harboe-Schmidt JE, Luthringer D, Brackert S and Silberman AW: Colorectal cancer metastasis presenting as a testicular mass: case report and review of the literature. Am Surg 73: 79-81, 2007. 
7. Oshima T, Kunisaki C, Yoshihara K, et al: Clinicopathological significance of the gene expression of matrix metalloproteinases and reversion-inducing cysteine-rich protein with Kazal motifs in patients with colorectal cancer: MMP-2 gene expression is a useful predictor of liver metastasis from colorectal cancer. Oncol Rep 19: 1285-1291, 2008.

8. Jensen SA, Vainer B, Bartels A, Brunner N and Sorensen JB: Expression of matrix metalloproteinase 9 (MMP-9) and tissue inhibitor of metalloproteinases 1 (TIMP-1) by colorectal cancer cells and adjacent stroma cells - associations with histopathology and patients outcome. Eur J Cancer 46: 3233-3242, 2010.

9. Gershtein ES, Korotkova EA, Shcherbakov AM, Prorokov VV, Golovkov DA and Kushlinskii NE: Matrix metalloproteinases 7 and 9 and their types 1 and 4 tissue inhibitors in tumors and plasma of patients with colorectal cancer. Bull Exp Biol Med 143: 459-462, 2007.

10. Mysliwiec AG and Ornstein DL: Matrix metalloproteinases in colorectal cancer. Clin Colorectal Cancer 1: 208-219, 2002.

11. Mroczko B, Groblewska M, Okulczyk B, Kedra B and Szmitkowski M: The diagnostic value of matrix metalloproteinase 9 (MMP-9) and tissue inhibitor of matrix metalloproteinases 1 (TIMP-1) determination in the sera of colorectal adenoma and cancer patients. Int J Colorectal Dis 25 : $1177-1184,2010$

12. Groblewska M, Mroczko B and Szmitkowski M: The role of selected matrix metalloproteinases and their inhibitors in colorectal cancer development. Postepy Hig Med Dosw (Online) 64: 22-30, 2010 (In Polish)

13. Roeb E and Matern S: Matrix metalloproteinases: promoters of tumor invasion and metastasis - a review with focus on gastrointestinal tumors. Z Gastroenterol 39: 807-813, 2001 (In German).

14. Gullu IH, Kurdoglu M and Akalin I: The relation of gelatinase (MMP-2 and -9) expression with distant site metastasis and tumour aggressiveness in colorectal cancer. Br J Cancer 82: 249, 2000

15. Takeha S, Fujiyama Y, Bamba T, Sorsa T, Nagura H and Ohtani H: Stromal expression of MMP-9 and urokinase receptor is inversely associated with liver metastasis and with infiltrating growth in human colorectal cancer: a novel approach from immune/inflammatory aspect. Jpn J Cancer Res 88: 72-81, 1997.

16. Dziki L, Przybylowska K, Majsterek I, Trzcinski R, Mik M and Sygut A: A/G polymorphism of the MMP-7 gene promoter region in colorectal cancer. Pol Przegl Chir 83: 622-626, 2011.

17. Ichikawa Y, Ishikawa T, Momiyama N, et al: Function of MMP-7 in colorectal cancer. Nihon Rinsho 61 (Suppl 7): 209-214, 2003 (In Japanese).

18. Thorp E, Vaisar T, Subramanian M, Mautner L, Blobel C and Tabas I: Shedding of the Mer tyrosine kinase receptor is mediated by ADAM17 protein through a pathway involving reactive oxygen species, protein kinase Cdelta and p38 mitogen-activated protein kinase (MAPK). J Biol Chem 286: 33335-33344, 2011.

19. Lou X, Zhou Q, Yin Y, Zhou C and Shen Y: Inhibition of the met receptor tyrosine kinase signaling enhances the chemosensitivity of glioma cell lines to CDDP through activation of p38 MAPK pathway. Mol Cancer Ther 8: 1126-1136, 2009.

20. Narkar V,Hussain T and Lokhandwala M: Role of tyrosine kinase and p44/42 MAPK in D(2)-like receptor-mediated stimulation of $\mathrm{Na}(+), \mathrm{K}(+)$-ATPase in kidney. Am J Physiol Renal Physiol 282 F697-F702, 2002.

21. Hinohara K, Kobayashi S, Kanauchi H, et al: ErbB receptor tyrosine kinase/NF-kappaB signaling controls mammosphere formation in human breast cancer. Proc Natl Acad Sci USA 109: 6584-6589, 2012.

22. Lee YJ, Han JY, Byun J, et al: Inhibiting Mer receptor tyrosine kinase suppresses STAT1, SOCS1/3 and NF-kappaB activation and enhances inflammatory responses in lipopolysaccharideinduced acute lung injury. J Leukoc Biol 91: 921-932, 2012.

23. Petro JB, Castro I, Lowe J and Khan WN: Bruton's tyrosine kinase targets NF-kappaB to the bcl-x promoter via a mechanism involving phospholipase C-gamma2 following B cell antigen receptor engagement. FEBS Lett 532: 57-60, 2002

24. Kawabata K, Murakami A and Ohigashi H: Citrus auraptene targets translation of MMP-7 (matrilysin) via ERK1/2-dependent and mTOR-independent mechanism. FEBS Lett 580: 5288-5294, 2006.

25. Brenneisen P, Wenk J, Wlaschek M, Krieg T and ScharffetterKochanek K: Activation of p70 ribosomal protein S6 kinase is an essential step in the DNA damage-dependent signaling pathway responsible for the ultraviolet $\mathrm{B}$-mediated increase in interstitial collagenase (MMP-1) and stromelysin-1 (MMP-3) protein levels in human dermal fibroblasts. J Biol Chem 275: 4336-4344, 2000.
26. Mosaad MS, Mohsen KM, Emad KM, Abotaleb N, Salwa NM and Marwa AF: Novel 6,8-dibromo-4(3H)-quinazolinone derivatives of promising anti-inflammatory and analgesic properties. Acta Pol Pharm 67: 159-171, 2010

27. Bekhit AA, Habib NS and Park JY: Synthesis of some thiazolyl and thiadiazolyl derivatives of $4(3 \mathrm{H})$-quinazolinone as antiinflammatory-antimicrobial agents. Boll Chim Farm 143: 34-39, 2004.

28. Hour MJ, Tsai SC, Wu HC, et al: Antitumor effects of the novel quinazolinone MJ-33: Inhibition of metastasis through the MAPK, AKT, NF- $\kappa$ B and AP-1 signaling pathways in DU145 human prostate cancer cells. Int J Oncol 41: 1513-1519, 2012.

29. Chen KT, Hour MJ, Tsai SC, et al: The novel synthesized 6-fluoro(3-fluorophenyl)-4-(3-methoxyanilino)quinazoline (LJJ-10) compound exhibits anti-metastatic effects in human osteosarcoma U-2 OS cells through targeting insulin-like growth factor-I receptor. Int J Oncol 39: 611-619, 2011.

30. Hour MJ, Yang JS, Chen TL, et al: The synthesized novel fluorinated compound (LJJ-10) induces death receptor- and mitochondria-dependent apoptotic cell death in the human osteogenic sarcoma U-2 OS cells. Eur J Med Chem 46: 2709-2721, 2011.

31. Wang MH, Padhye SS, Guin S, Ma Q and Zhou YQ: Potential therapeutics specific to c-MET/RON receptor tyrosine kinases for molecular targeting in cancer therapy. Acta Pharmacol Sin 31: 1181-1188, 2010.

32. Uckun FM, Vassilev A and Tibbles H: Non-receptor tyrosine kinases as molecular targets for patient tailored cancer therapy. Anticancer Agents Med Chem 7: 593, 2007.

33. Gschwind A, Fischer OM and Ullrich A: The discovery of receptor tyrosine kinases: targets for cancer therapy. Nat Rev Cancer 4: 361-370, 2004.

34. Brunelleschi S, Penengo L, Santoro MM and Gaudino G: Receptor tyrosine kinases as target for anti-cancer therapy. Curr Pharm Des 8: 1959-1972, 2002

35. Rodig SJ and Shapiro GI: Crizotinib, a small-molecule dual inhibitor of the c-Met and ALK receptor tyrosine kinases. Curr Opin Investig Drugs 11: 1477-1490, 2010.

36. You WK, Sennino B, Williamson CW, et al: VEGF and c-Met blockade amplify angiogenesis inhibition in pancreatic islet cancer. Cancer Res 71: 4758-4768, 2011.

37. Garouniatis A, Zizi-Sermpetzoglou A, Rizos S, Kostakis A, Nikiteas $\mathrm{N}$ and Papavassiliou AG: FAK, CD44v6, c-Met and EGFR in colorectal cancer parameters: tumour progression, metastasis, patient survival and receptor crosstalk. Int $\mathrm{J}$ Colorectal Dis 28: 9-18, 2013

38. Zhao J, Zhang X and Xin Y: Up-regulated expression of Ezrin and c-Met proteins are related to the metastasis and prognosis of gastric carcinomas. Histol Histopathol 26: 1111-1120, 2011.

39. Liska D, Chen CT, Bachleitner-Hofmann T, Christensen JG and Weiser MR: HGF rescues colorectal cancer cells from EGFR inhibition via MET activation. Clin Cancer Res 17: 472-482, 2011.

40. Cunningham MP, Thomas H, Marks C, Green M, Fan Z and Modjtahedi H: Co-targeting the EGFR and IGF-IR with anti-EGFR monoclonal antibody ICR62 and the IGF-IR tyrosine kinase inhibitor NVP-AEW541 in colorectal cancer cells. Int J Oncol 33: 1107-1113, 2008.

41. Yang JS, Wu CC, Kuo CL, et al: Solanum lyratum extracts induce extrinsic and intrinsic pathways of apoptosis in WEHI-3 murine leukemia cells and inhibit allograft tumor. Evid Based Complement Alternat Med 2012: 254960, 2012.

42. Jia W, Hegde VL, Singh NP, et al: Delta9-tetrahydrocannabinolinduced apoptosis in Jurkat leukemia $\mathrm{T}$ cells is regulated by translocation of Bad to mitochondria. Mol Cancer Res 4: 549-562, 2006.

43. He Z, Cho YY, Ma WY, Choi HS, Bode AM and Dong Z: Regulation of ultraviolet B-induced phosphorylation of histone $\mathrm{H} 3$ at serine 10 by Fyn kinase. J Biol Chem 280: 2446-2454, 2005.

44. Jost M, Huggett TM, Kari C, Boise LH and Rodeck U: Epidermal growth factor receptor-dependent control of keratinocyte survival and Bcl-xL expression through a MEK-dependent pathway. J Biol Chem 276: 6320-6326, 2001.

45. Abdel-Ghany M, el-Gendy K, Zhang S and Racker E: Control of src kinase activity by activators, inhibitors and substrate chaperones. Proc Natl Acad Sci USA 87: 7061-7065, 1990.

46. Spano JP, Milano G and Baselga J: EGFR/VEGF signalling pathway in colorectal cancer: the way we are! Bull Cancer 92: S3-S4, 2005. 
47. Ishikawa $\mathrm{T}$, Uetake $\mathrm{H}$ and Sugihara K: Anti-EGFR antibody therapy for colorectal cancer. Nihon Rinsho 70: 2152-2158, 2012 (In Japanese).

48. Mimori K, Yamashita K, Ohta M, et al: Coexpression of matrix metalloproteinase-7 (MMP-7) and epidermal growth factor (EGF) receptor in colorectal cancer: an EGF receptor tyrosine kinase inhibitor is effective against MMP-7-expressing cancer cells. Clin Cancer Res 10: 8243-8249, 2004.

49. Yang JS, Hour MJ, Huang WW, Lin KL, Kuo SC and Chung JG: MJ-29 inhibits tubulin polymerization, induces mitotic arrest and triggers apoptosis via cyclin-dependent kinase 1-mediated Bcl-2 phosphorylation in human leukemia U937 cells. J Pharmacol Exp Ther 334: 477-488, 2010.

50. Lu CC, Yang JS, Chiang JH, et al: Inhibition of invasion and migration by newly synthesized quinazolinone MJ-29 in human oral cancer CAL 27 cells through suppression of MMP-2/9 expression and combined down-regulation of MAPK and AKT signaling. Anticancer Res 32: 2895-2903, 2012.

51. Pospisil P, Korideck H, Wang K, Yang Y, Iyer LK and Kassis AI Computational and biological evaluation of quinazolinone prodrug for targeting pancreatic cancer. Chem Biol Drug Des 79: 926-934, 2012

52. Wu YC, Hour MJ, Leung WC, et al: 2-(Naphthalene-1-yl)-6pyrrolidinyl-4-quinazolinone inhibits skin cancer M21 cell proliferation through aberrant expression of microtubules and the cell cycle. J Pharmacol Exp Ther 338: 942-951, 2011.

53. Lu CC, Yang JS, Chiang JH, et al: Novel quinazolinone MJ-29 triggers endoplasmic reticulum stress and intrinsic apoptosis in murine leukemia WEHI-3 cells and inhibits leukemic mice. PLoS One 7: e36831, 2012.

54. Chiu YJ, Hour MJ, Lu CC, et al: Novel quinazoline HMJ-30 induces U-2 OS human osteogenic sarcoma cell apoptosis through induction of oxidative stress and up-regulation of ATM p53 signaling pathway. J Orthop Res 29: 1448-1456, 2011.

55. Yang JS, Hour MJ, Kuo SC, Huang LJ and Lee MR: Selective induction of G2/M arrest and apoptosis in HL-60 by a potent anticancer agent, HMJ-38. Anticancer Res 24: 1769-1778, 2004.

56. Garcia ED: Targeted therapy for cancer: anti-tyrosine kinase receptor agents. An R Acad Nac Med (Madr) 124: 171-184, 2007 (In Spanish).

57. Myers MV, Manning HC, Coffey RJ and Liebler DC: Protein expression signatures for inhibition of epidermal growth factor receptor-mediated signaling. Mol Cell Proteomics 11: M111 015222, 2012

58. Goldwasser F: Treatment of metastatic colorectal cancer: an illustration of the changes in the cancer paradigms. Presse Med 41: 46-50, 2012 (In French).

59. Shaw PH and Adams RA: Where now for anti-EGF receptor therapies in colorectal cancer? Expert Rev Anticancer Ther 11: 1543-1553, 2011

60. Takhar AS, Eremin O and Watson SA: The role of gastrin in colorectal carcinogenesis. Surgeon 2: 251-257, 2004.

61. Cohen RB: Epidermal growth factor receptor as a therapeutic target in colorectal cancer. Clin Colorectal Cancer 2: 246-251, 2003.

62. Yokozaki H and Tahara E: Metastasis-related genes. Gan To Kagaku Ryoho 21: 2541-2548, 1994 (In Japanese).

63. Wilson KJ, Gilmore JL, Foley J, Lemmon MA and Riese DJ II: Functional selectivity of EGF family peptide growth factors: implications for cancer. Pharmacol Ther 122: 1-8, 2009.

64. Broadbridge VT, Karapetis CS and Price TJ: Cetuximab in metastatic colorectal cancer. Expert Rev Anticancer Ther 12: 555-565, 2012.
65. Harding $\mathrm{J}$ and Burtness B: Cetuximab: an epidermal growth factor receptor chemeric human-murine monoclonal antibody. Drugs Today (Barc) 41: 107-127, 2005.

66. Takayama T, Goji T, Taniguchi T and Inoue A: Chemoprevention of colorectal cancer-experimental and clinical aspects. J Med Invest 56: 1-5, 2009.

67. Ho BY, Wu YM, Chang KJ and Pan TM: Dimerumic acid inhibits SW620 cell invasion by attenuating $\mathrm{H}(2) \mathrm{O}(2)$-mediated MMP-7 expression via JNK/C-Jun and ERK/C-Fos activation in an AP-1-dependent manner. Int J Biol Sci 7: 869-880, 2011.

68. Zugowski C, Lieder F, Muller A, et al: STAT3 controls matrix metalloproteinase-1 expression in colon carcinoma cells by both direct and AP-1-mediated interaction with the MMP-1 promoter. Biol Chem 392: 449-459, 2011.

69. Fang YJ, Lu ZH, Wang GQ, et al: Elevated expressions of MMP7, TROP2 and survivin are associated with survival, disease recurrence and liver metastasis of colon cancer. Int J Colorectal Dis 24: 875-884, 2009.

70. Shin JE, Jung SA, Kim SE, et al: Expression of MMP-2, HIF-1alpha and VEGF in colon adenoma and colon cancer. Korean J Gastroenterol 50: 9-18, 2007 (In Korean).

71. Zinzindohoue F, Lecomte T, Ferraz JM, et al: Prognostic significance of MMP-1 and MMP-3 functional promoter polymorphisms in colorectal cancer. Clin Cancer Res 11: 594-599, 2005.

72. Yamamoto $\mathrm{H}$, Itoh $\mathrm{F}$, Senota $\mathrm{A}$, et al: Expression of matrix metalloproteinase matrilysin (MMP-7) was induced by activated Ki-ras via AP-1 activation in SW1417 colon cancer cells. J Clin Lab Anal 9: 297-301, 1995.

73. Ueda T, Sasaki M, Elia AJ, et al: Combined deficiency for MAP kinase-interacting kinase 1 and 2 (Mnk1 and Mnk2) delays tumor development. Proc Natl Acad Sci USA 107: 13984-13990, 2010.

74. Joshi S, Kaur S, Redig AJ, et al: Type I interferon (IFN)dependent activation of Mnk1 and its role in the generation of growth inhibitory responses. Proc Natl Acad Sci USA 106: 12097-12102, 2009.

75. Zhang Y, Li Y and Yang DQ: Phosphorylation of eIF-4E positively regulates formation of the eIF- $4 \mathrm{~F}$ translation initiation complex following DNA damage. Biochem Biophys Res Commun 367: 54-59, 2008.

76. Duncan RF, Peterson H and Sevanian A: Signal transduction pathways leading to increased eIF4E phosphorylation caused by oxidative stress. Free Radic Biol Med 38: 631-643, 2005.

77. Populo H, Lopes JM and Soares P: The mTOR signalling pathway in human cancer. Int J Mol Sci 13: 1886-1918, 2012.

78. Hong S, Mannan AM and Inoki K: Evaluation of the nutrientsensing mTOR pathway. Methods Mol Biol 821: 29-44, 2012.

79. Nyfeler B, Bergman P, Triantafellow E, et al: Relieving autophagy and 4EBP1 from rapamycin resistance. Mol Cell Biol 31: 2867-2876, 2011

80. Ha SH, Kim DH, Kim IS, et al: PLD2 forms a functional complex with $\mathrm{mTOR} /$ raptor to transduce mitogenic signals. Cell Signal 18: 2283-2291, 2006.

81. Arvisais EW, Romanelli A,Hou X and Davis JS: AKT-independent phosphorylation of TSC2 and activation of mTOR and ribosomal protein S6 kinase signaling by prostaglandin F2alpha. J Biol Chem 281: 26904-26913, 2006.

82. Hannan KM, Brandenburger Y, Jenkins A, et al: mTOR-dependent regulation of ribosomal gene transcription requires S6K1 and is mediated by phosphorylation of the carboxy-terminal activation domain of the nucleolar transcription factor UBF. Mol Cell Biol 23: 8862-8877, 2003. 